\title{
Extraskeletal multiple myeloma presenting with an atrial mass: a case report and a review of the literature
}

Federica Vigo ${ }^{1 *}$, Patrizia Ciammella ${ }^{1}$, Riccardo Valli ${ }^{2}$, Elisabetta Cagni ${ }^{3}$ and Cinzia lotti ${ }^{1}$

\begin{abstract}
Introduction: Extraskeletal presentation at diagnosis or during the course of multiple myeloma is a rare event. The prognosis is usually very poor. At the moment there is no agreed gold standard for the treatment of this presentation.

Case presentation: A 79-year-old Caucasian woman was treated at our hospital for right atrial myeloma localization. Our patient showed the following signs and symptoms of congestive heart failure: dyspnea, hypotension, cyanosis and facial edema. Surgery was not considered feasible due to the extent of the disease. Our patient underwent external-beam radiation therapy using an intensity modulated technique, thus obtaining a persistent complete remission. Our patient has been in continuous complete local remission for 25 months since the end of radiotherapy.

Conclusion: The role of radiotherapy is not defined in multiple myeloma with extraskeletal presentation. Our regimen seems to be effective in controlling the disease in this patient.

This case report adds to the existing literature as it describes an unusual presentation of the disease and a new therapeutic approach to this rare presentation of multiple myeloma.
\end{abstract}

\section{Introduction}

Multiple myeloma (MM) is a malignant disorder of the plasma cells that is commonly associated with bone marrow plasmacytosis and usually restricted only to the bone marrow. Extraskeletal (ES) localization at diagnosis or during the course of MM is a rare event with a very aggressive course. The prognosis is extremely poor, especially when the diagnosis of ES localization is concurrent with the diagnosis of MM [1]. Patients presenting with ES involvement at diagnosis have significantly shorter progression-free survival compared with other patients with MM (18 months versus 30 months, $\mathrm{P}=0.003$ ), whereas the median overall survival is not statistically different between the two groups (36 and 43 months, respectively, $\mathrm{P}=0.36$ ) [2].

Intracardiac localization is extremely rare, with only a few case reports [2-8].

\footnotetext{
* Correspondence: federica.vigo@tiscali.it

'Department of Advanced Technologies, Radiation Oncology Unit,

Arcispedale Santa Maria Nuova - IRCCS, Reggio Emilia, Italy

Full list of author information is available at the end of the article
}

We present the case of a patient with a right atrial mass that led to signs and symptoms of congestive heart failure.

\section{Case presentation}

A healthy 79-year-old Caucasian woman was referred to our hospital with a diagnosis of stage III immunoglobulin A-lambda MM with numerous osteolytic areas (bilateral iliac wings, T3 to T4) and cardiologic symptoms of pulmonary embolism. Computed tomography (CT) of her chest documented the presence of a right atrial mass $(42 \mathrm{~mm} \times 53 \mathrm{~mm})$, confirmed by subsequent magnetic resonance imaging (MRI) and fluorine-18fluorodeoxyglucose positron emission tomography (F18FDG PET). A transesophageal echocardiogram revealed a large pericardial effusion with evidence of cardiac tamponade and a large right atrial mass encasing her interatrial septum and extending into her left atrium. Histologic specimens of a bone marrow biopsy demonstrated the presence of tiny aggregates of atypical plasma

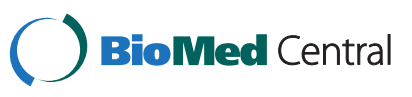


cells with asynchronous morphology, positive for cluster of differentiation 138.

Our patient was treated with four cycles of bortezomib, four cycles of melphalan and prednisone and another four cycles of bortezomib, achieving a lessening of the symptoms and a stability of the cardiac disease. Pharmacological toxicity was not significant.

Nine months later, our patient developed a painful bone relapse. The pain was severe, constant and localized primarily in her sacrum and the right iliac wing. The pain increased to some extent with movement. Our patient received local radiotherapy on both sites (2000cGy/5 fractions), achieving a reduction in symptoms and an improvement of her performance status.
One year after the initial diagnosis, our patient presented to our emergency department because of the new appearance of signs and symptoms of congestive heart failure: dyspnea, hypotension, cyanosis and facial edema.

CT of her chest revealed an increase in the size of the mass $(78 \mathrm{~mm} \times 84 \mathrm{~mm})$, which appeared to infiltrate her right pulmonary vein and superior vena cava for approximately $21 \mathrm{~mm}$, causing neoplastic thrombosis of her right subclavian vein (Figure 1A). These findings were confirmed by echocardiography and F18-FDG PET (Figure 1B).

Restaging examinations documented stable bone disease.

Our patient was evaluated by a surgeon for possible surgery on her right atrium, but she was considered inoperable due to the extent of the disease. The diagnosis
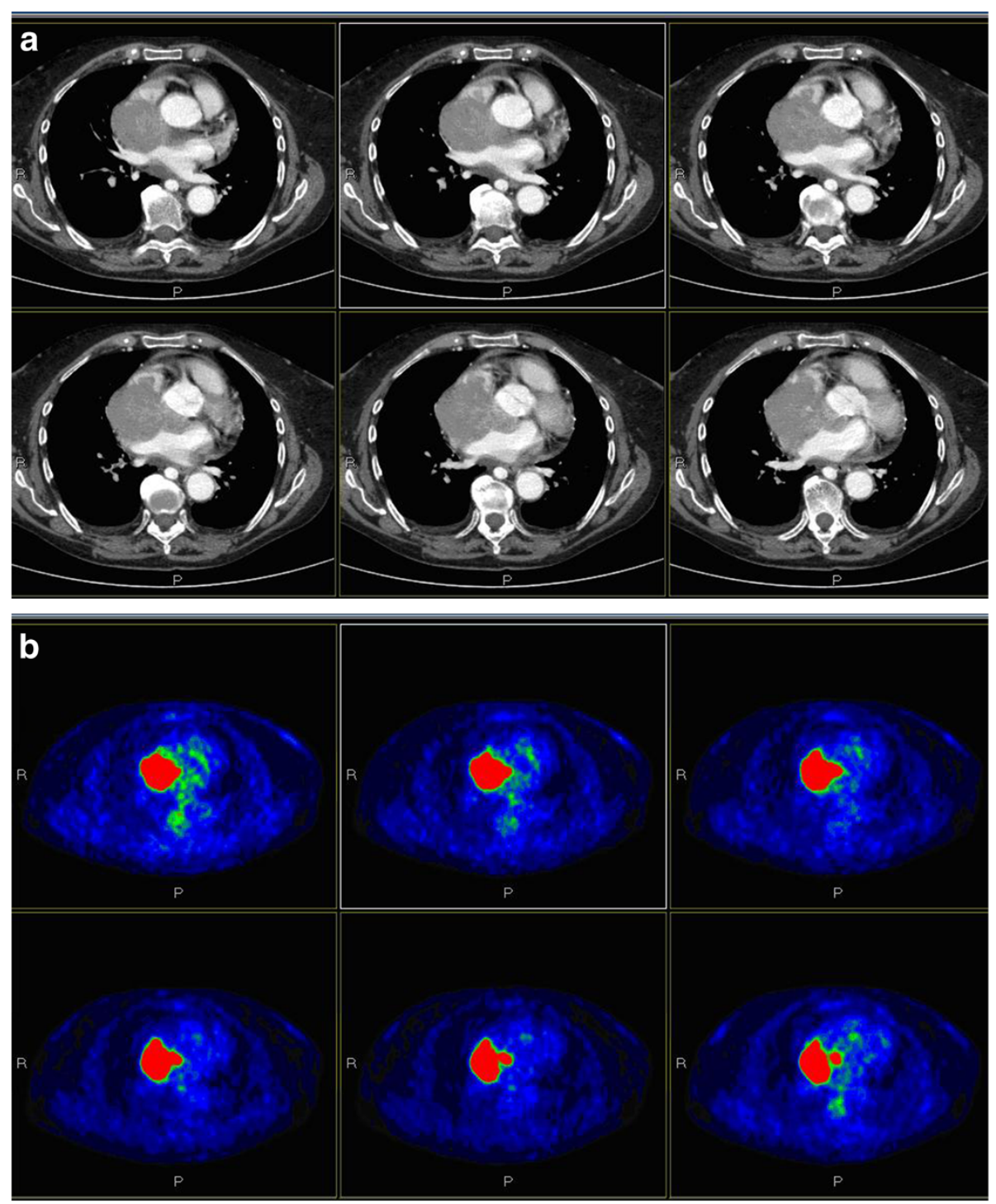

Figure 1 Radiographic images of the mass. (A) Computed tomography of the chest documenting the atrial mass; (B) fluorine-18fluorodeoxyglucose positron emission tomography confirming this data. 


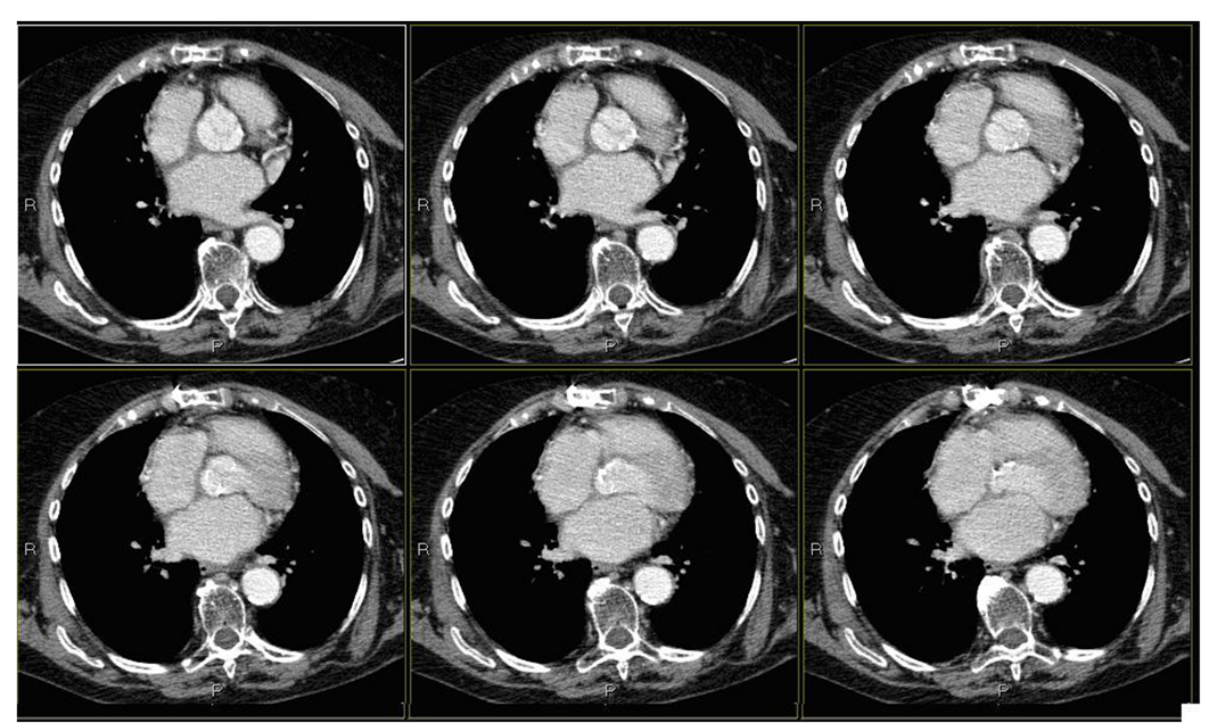

Figure 2 Computed tomography of the chest performed one year after the end of radiotherapy. Image describes total disappearance of the lesion.

of atrial localization of malignant plasmacytoma was confirmed via examination of a biopsy specimen. In order to obtain rapid control of the intracardiac disease, radiation to the cardiac mass was started.

External-beam radiation, totaling 3000cGy in 10 daily fractions of 300cGy, each with $6 \mathrm{mV}$ photons, was delivered using the intensity modulated radiation therapy (IMRT) technique.

Our patient was immobilized in the supine position with a wing board and target localization was accomplished using CT simulation. The volumes of interest were identified on each axial CT slice. The gross tumor volume was defined as the gross extent of the tumor shown by imaging (CT, MRI and PET); the clinical target volume was defined as the gross tumor volume plus a margin for potential microscopic spread $(5 \mathrm{~mm})$; and, in order to account for organ motion and patient setup errors, the planning target volume was defined by adding a $1 \mathrm{~cm}$ margin to the clinical target volume. Treatment planning was performed using an inverse planning algorithm in a tomotherapy planning system and our patient was treated with an IMRT delivered with tomotherapy.

The treatment was generally well tolerated; our patient showed no symptoms suggestive of radiation-induced toxicity. Her symptoms immediately improved with a decrease in generalized edema and improved performance status. A transesophageal echocardiogram performed three weeks from the end of the radiotherapy confirmed a significant decrease in tumor size in her right atrium.

Due to our patient's age and good condition, the medical staff chose a 'wait and see' approach. Three months later, repeat chest and abdominal CT scans showed complete remission of the cardiac disease, but progressive bone disease.
The worsening of the general conditions of our patient, due to other causes, meant that she was subjected to supportive care for two months. After the improvement of her health status, our patient started maintenance chemotherapy with lenalidomide and she is currently tolerating it well.

In a new CT scan of her chest done eighteen months after the end of the radiotherapy (Figure 2), complete remission of the cardiac disease was confirmed.

Currently, our patient is generally in good condition and shows no significant cardiac symptoms. Recently performed chest and abdominal CT documented stability of the disease in known locations, but highlighted the emergence of an axillary mass, for which we are programming a new radiation treatment in view of her good response to previous radiotherapy.

\section{Discussion}

There are few previous case reports of intracardiac malignant plasmacytomas (Table 1); for this reason, experience with the treatment of this involvement is limited. Furthermore, in some cases, the diagnosis was made during autopsy $[1,6]$.

Interestingly, the right atrium seems to be the predominant location of plasmacytomas involving the heart. Although its exact etiology is unknown, the presence of cell surface adhesion molecules on the malignant plasma cell and their interaction with permissive growth factors on the endothelial lining of the heart have been considered as contributing factors [7].

The most optimal therapeutic strategy for intracardiac malignant plasmacytoma is not well defined. Treatment options include, when possible, surgical resection or 
Table 1 Review of the literature

\begin{tabular}{|c|c|c|c|c|c|}
\hline Reference & $\begin{array}{l}\text { Extramedullary } \\
\text { localization }\end{array}$ & Diagnostic test & Local therapy & Outcome portion & Cause of death \\
\hline $\begin{array}{l}\text { Goldberg and } \\
\text { Mori [3] }\end{array}$ & $\begin{array}{l}\text { Pericardial effusion } \\
\text { and cardiac } \\
\text { tamponade }\end{array}$ & Autopsy & $N R$ & $\begin{array}{l}\text { Death and } \\
\text { postmortem } \\
\text { diagnosis of } \\
\text { pericardial } \\
\text { involvement }\end{array}$ & Heart failure \\
\hline Garrett et al. [4] & $\begin{array}{l}\text { Pericardial and } \\
\text { myocardial involvement } \\
\text { and cardiac tamponade }\end{array}$ & Chest X-ray & $\begin{array}{l}\text { Transthoracic } \\
\text { pericardiocentesis }\end{array}$ & $\begin{array}{l}\text { No medical } \\
\text { therapy for heart } \\
\text { involvement }\end{array}$ & Heart failure \\
\hline Imamura et al. [5] & $\begin{array}{l}\text { Pleural and pericardial } \\
\text { effusion }\end{array}$ & NR & $\begin{array}{l}\text { Pericardiocentesis, } \\
\text { intrapericardial injection } \\
\text { of OK-432, RT } \\
\text { (1400rad), peplomycin, } \\
\text { vincristine and } \\
\text { prednisolone }\end{array}$ & $C R$ & $\begin{array}{l}\text { Death seven } \\
\text { months after } \\
\text { diagnosis for } \\
\text { progression of } \\
\text { systemic disease }\end{array}$ \\
\hline Mitchell et al. [6] & $\begin{array}{l}\text { Pericardial effusion } \\
\text { and substantial } \\
\text { hypertrophy of the } \\
\text { right and left ventricular } \\
\text { walls, infiltrative } \\
\text { cardiomyopathy }\end{array}$ & Echocardiogram & $\begin{array}{l}\text { Bleomycin } 20 \mathrm{~mL} \text { in } 30 \mathrm{~mL} \\
\text { of normal saline solution } \\
\text { introduced into the } \\
\text { pericardial space }\end{array}$ & $\begin{array}{l}\text { No recurrent } \\
\text { pericardial } \\
\text { effusion }\end{array}$ & $\begin{array}{l}36 \text { hours after } \\
\text { his last echocardiogram, } \\
\text { the patient became } \\
\text { acutely hypoxemic and } \\
\text { died suddenly } \\
\text { (massive pulmonary } \\
\text { embolism)-no autopsy }\end{array}$ \\
\hline Ueda et al. [8] & $\begin{array}{l}\text { A-V sulcus between } \\
\text { the left atrium } \\
\text { and left ventricle } \\
\text { (diameter } 3 \mathrm{~cm} \text { ) } \\
\text { Cardiac tamponade }\end{array}$ & TEE & $\begin{array}{l}\text { Cisplatin-betamethasone } \\
\text { into the pericardial cavity }\end{array}$ & $C R$ & $\begin{array}{l}\text { Death from bacterial } \\
\text { pneumonia } 182 \text { days } \\
\text { after the first admission } \\
\text { - no autopsy }\end{array}$ \\
\hline Champeaux et al. [9] & $\begin{array}{l}\text { Myocardium and } \\
\text { coronary vessels }\end{array}$ & Autopsy & NR & NR & Respiratory failure \\
\hline Owens et al. [10] & $\begin{array}{l}\text { Pericardial effusion } \\
\text { and large mass } \\
\text { lesions in the left } \\
\text { and right atria. } \\
\text { Cardiac tamponade }\end{array}$ & $\begin{array}{l}\text { Echocardiography, } \\
\text { chest radiography } \\
\text { and } \mathrm{CT} \text { of the heart }\end{array}$ & $\begin{array}{l}\text { Drainage of the effusion, } \\
\text { RT to the heart ( } 30 \mathrm{~Gy} / 10 \mathrm{fr} \\
\text { over two weeks with } \\
6 \mathrm{mV} \text { photons) }\end{array}$ & $\begin{array}{l}\text { Almost complete } \\
\text { tumor regression }\end{array}$ & Alive with disease \\
\hline Zeiser et al. [11] & $\begin{array}{l}\text { Pericardial and } \\
\text { pleural effusion }\end{array}$ & $\begin{array}{l}\text { Echocardiography, } \\
\text { CT of the thorax }\end{array}$ & $\begin{array}{l}\text { High-dose systemic } \\
\text { dexamethasone }\end{array}$ & $\begin{array}{l}\text { Stable disease } \\
\text { for six weeks }\end{array}$ & $\begin{array}{l}\text { Death from } \\
\text { pneumonia }\end{array}$ \\
\hline Songul et al. [12] & $\begin{array}{l}\text { Left lobe and } \\
\text { isthmus of thyroid, } \\
\text { bilateral pleural } \\
\text { effusion and a } 1 \mathrm{~cm} \\
\text { pericardial effusion } \\
\text { around the } \\
\text { left ventricle. }\end{array}$ & Chest radiography, CT & $\begin{array}{l}\text { Chemotherapy, } \\
\text { RT and supportive } \\
\text { measures. }\end{array}$ & Death & $\begin{array}{l}\text { Disease } \\
\text { progression }\end{array}$ \\
\hline Franzese et al. [13] & Pericardium infiltration & $\begin{array}{l}\text { Chest radiography, } \\
\mathrm{CT} \text { and } \\
\text { echocardiogram. }\end{array}$ & $\begin{array}{l}\text { Surgical resection } \\
\text { of the intrapericardial } \\
\text { mass }\end{array}$ & NR & NR \\
\hline Paulus et al. [14] & $\begin{array}{l}\text { Large pericardial effusion, } \\
\text { large right atrial mass } \\
\text { encasing the interatrial } \\
\text { septum extending into } \\
\text { the left atrium, cardiac } \\
\text { tamponade }\end{array}$ & $\begin{array}{l}\text { Chest radiography, } \\
\text { TEE, MRI } \\
\text { of the chest, } \\
\text { biopsy of the } \\
\text { atrial mass }\end{array}$ & $\begin{array}{l}\text { Pericardiocentesis, } \\
\text { high-dose } \\
\text { dexamethasone, } \\
\text { bortezomib } \\
\text { and lenalidomide } \\
\text { RT to the cardiac mass } \\
\text { (20Gy/10fr with } \\
6 \mathrm{mV} \text { photons using an } \\
\text { Anterior-Posterior technique } \\
\text { Consolidation unspecified } \\
\text { chemotherapy (bortezomib, } \\
\text { cyclophosphamide, } \\
\text { dexamethasone) }\end{array}$ & $\begin{array}{l}\text { Significant decrease } \\
\text { in tumor size in the } \\
\text { right atrium and the } \\
\text { aortic root }\end{array}$ & NR \\
\hline
\end{tabular}


intrapericardial administration of bleomycin, cisplatin, or betamethasone with only transitory effects, or radiation therapy (with different doses).

Until now, notwithstanding the wide range of approaches available, there is no unanimous agreement on the proper mode of treatment for intracardiac malignant plasmacytoma.

If we analyze the studies reported in Table 1, it is quite evident how the radiation therapy, in cases in which it was administered, especially when associated with systemic therapy $[5,10,14]$, has resulted in a better clinical and instrumental response than the other treatments, especially considering the better toxicity profile of radiation therapy compared with surgery. Another possible alternative would seem to be the intrapericardial injection of different drugs, that, in the few cases reported in literature $[5,6,8]$, seem to have allowed reasonable local control.

Our patient's clinical presentation of congestive heart failure was initially a result of tamponade and also a result of the anatomic location of the MM in her right atrium. In this case, the radiation treatment was useful, not only to reduce the bone pain, but also to decrease the cardiac disease burden with an immediate improvement in our patient's symptoms and performance status.

After a follow-up of 25 months, our patient is alive with good general condition and she has no limitations to her daily activities, considering her age and maintenance therapy.

This result leads us to suggest the possibility to obtain not only control of the symptoms, but also a beneficial effect in delaying disease progression.

\section{Conclusions}

ES tumors are a rare manifestation of MM, with a cumulative incidence of $4.6 \%$ of MM cases. The best treatment strategy for these tumors is not yet well defined. The role of radiotherapy, which is the standard treatment for a solitary plasmacytoma, is much less defined in MM with ES disease, where radiotherapy is usually associated with systemic treatment with chemotherapy or novel agents.

Studies aimed at defining the best therapeutic strategy for ES MM are needed.

\section{Consent}

Written informed consent was obtained from the patient for publication of this manuscript and accompanying images. A copy of the written consent is available for review by the Editor-in-Chief of this journal.

\section{Competing interests}

The authors declare that they have no competing interests.

\section{Authors' contributions}

FV has contributed to the clinical evaluation of the patient and was a major contributor in writing the manuscript; PC was the radiation oncologist of reference of the patient and contributed in writing the manuscript; $\mathrm{Cl}$, the Director of the Radiation Oncology Unit, has contributed to patient management and therapeutic decisions; RV analyzed and interpreted the patient data from a histological point of view; EC drew up the plan of radiotherapy. All authors read and approved the final manuscript.

\section{Author details}

'Department of Advanced Technologies, Radiation Oncology Unit, Arcispedale Santa Maria Nuova - IRCCS, Reggio Emilia, Italy. ${ }^{2}$ Department of Oncology, Pathology Unit, Arcispedale Santa Maria Nuova - IRCCS, Reggio Emilia, Italy. ${ }^{3}$ Medical Physics Department, Arcispedale Santa Maria Nuova IRCCS, Reggio Emilia, Italy.

Received: 7 February 2012 Accepted: 8 June 2012

Published: 10 August 2012

\section{References}

1. Damaj G, Mohty M, Vey N, Dincan E, Bouabdallah R, Faucher C, Stoppa AM, Gastaut JA: Features of extramedullary and extraosseous multiple myeloma: a report of 19 patients from a single center. Eur J Haematol 2004, 73(6):402-406.

2. Varettoni M, Corso A, Pica G, Mangiacavalli S, Pascutto C, Lazzarino M: Incidence, presenting features and outcome of extramedullary disease in multiple myeloma: a longitudinal study on 1003 consecutive patients. Ann Oncol 2010, 21:325-330.

3. Goldberg E, Mori K: Multiple myeloma: isolated visceral (epicardial) involvement and cardiac tamponade. Chest 1970, 57:584-587.

4. Garrett TJ, McCans JL, Parker JO: Fatal involvement of the heart with multiple myeloma. Can Med Ass J 1972, 107(10):979-980.

5. Imamura T, Tamura K, Taguchi T, Makino S, Seita M: Intrapericardial instillation of OK-432 for the management of malignant pericardial effusion: report of three cases. Jpn J Med 1989, 28(1):62-66.

6. Mitchell MA, Horneffer MD, Standford TJ: Multiple myeloma complicated by restrictive cardiomyopathy and cardiac tamponade. Chest 1993, 103:946-947.

7. Fernandez LA, Couban S, Sy R, Miller R: An unusual presentation of extramedullary plasmacytoma occurring sequentially in the testis, subcutaneous tissue, and heart. Am J Hematol 2001, 67:194-196.

8. Ueda T, Mizushige K, Kiyomoto H, Sakamoto S, Matsuo H: Transesophageal echocardiographic observation of multiple myeloma involving the pericardium: a case report. Jpn Circ J 2000, 64(1):80-82.

9. Champeaux AL, Blaser $J \mathrm{~L}$, Myers JB, Schachte DT: Multiple myeloma involving the myocardium and coronary vessels. Arch Pathol Lab Med 2000, 124:910-912.

10. Owens P, Morgan-Hughes G, Kelly S, Ring N, Marshall J: Myeloma and a mass in the Heart. $J R$ Soc Med 2003, 96:288-289.

11. Zeiser R, Hackanson B, Bley TA, Finke J, Bertz H: Unusual cases in multiple myeloma and a dramatic response in metastatic lung cancer: Case 1. Multiple myeloma relapse presenting as malignant pericardial effusion. J Clin Oncol 2005, 23(1):230-231.

12. Serefhanoglu S, Sayinalp N, Haznedaroglu IC, Goker H, Cetiner D, Aksu S, Buyukasik Y, Ozcebe Ol: Extramedullary plasmacytomas of the thyroid and pericardium as initial presentation of multiple myeloma. Ann Hematol 2008, 87:853-854.

13. Franzese MG, leva R, Correale M, Palumbo G, Capalbo SF, Di Biase M: An extramedullary lesion in multiple myeloma: voluminous pericardial mass. Clin Cardiol 2009, 32(8):E73.

14. Paulus A, Swaika A, Miller KC, Spangenthal EJ, Guo R, Vonfricken K, Lee K, Chanan-Khan AA: Clinical relapse in a patient with multiple myeloma presenting as an atrial plasmacytoma. J Clin Oncol 2011, 29(3):e47-e49.

doi:10.1186/1752-1947-6-236

Cite this article as: Vigo et al.: Extraskeletal multiple myeloma presenting with an atrial mass: a case report and a review of the literature. Journal of Medical Case Reports 2012 6:236. 